\title{
PEMANFAATAN LIMBAH GENTENG SEBAGAI CAMPURAN SEMEN DAN PENAMBAHAN ZAT ADDITIV MASTER EASE TERHADAP BETON K-200
}

\author{
Jefrianto $^{* 1}$, Sigit Winarto ${ }^{2}$, Yosef Cahyo SP ${ }^{3}$. \\ ${ }^{1,2,3}$ Fakultas Teknik, Universitas Kadiri. \\ e-mail:*1jefrianto@gmail.com, ${ }^{2}$ sigit.winarto@unik-kediri.ac.id, \\ 3 yosef.cs@unik-kediri.ac.id.
}

\begin{abstract}
Concrete needs are increasingly increasing, so the need for material is also increasing. From this research, it is hoped to find innovations to reduce the amount of cement used by combining tile waste and additives in the manufacture of concrete. From this compressive strength research, it can be concluded that the concrete that has the highest average compressive strength is the addition of $5 \%$ tile waste from the amount of cement and 5\% additives of the amount of water with a compressive strength value of $212.44 \mathrm{~kg} / \mathrm{cm}^{2}$, and which has the lowest compressive strength value is concrete with the addition of tile waste $15 \%$ of the amount of cement and additives 5\% of the amount of water with a compressive strength value of $191.11 \mathrm{~kg}$ $/ \mathrm{cm}^{2}$. The most effective absorption and the specific gravity of the test were obtained from concrete combined with 10\% Tile Waste from cement and 5\% additive with an average water value of only 0.1589 liters and a specific gravity of only $2400.65 \mathrm{~kg} / \mathrm{m} 3$.
\end{abstract}

Keywords: $\quad$ Concrete, Tile Waste, Master Ease, Absorption

\begin{abstract}
Abstrak
Kebutuhan beton semakin lama semakin meningkat, sehingga kebutuhan akan bahan penyusunya juga kian meningkat. dari penelitian ini di harapkan dapat menemukan inovasi untuk mengurangi jumlah pemakaian semen dengan mengkombinasikan limbah genteng dan zat additive pada pembuatan beton.Dari penelitian kuat tekan ini dapat disimpulkan beton yang memiliki nilai kuat tekan rata-rata paling tinggi di miliki beton dengan penambahan Limbah Genteng 5\% dari semen dan zat additive 5\% dari air dengan nilai kuat tekan sebesar 212,44 Kg/cm², dan yang memiliki nilai kuat tekan paling rendah di miliki beton dengan penambahan Limbah Genteng 15\% dari semen dan zat additive 5\% dari air dengan nilai kuat tekan 191,11 $\mathrm{Kg} / \mathrm{cm}^{2}$. Daya absorbsi dan berat jenis paling efektif dari pengujian didapat dari beton berkombinasi Limbah Genteng $10 \%$ dari semen dan zat additive 5\% dengan jumlah nilai air rata - rata hanya sejumlah 0,1589 liter dan berat jenis hanya sebesar $2400,65 \mathrm{~kg} / \mathrm{m}^{3}$.
\end{abstract}

Kata Kunci : $\quad$ Beton, Limbah Genteng, Master Ease, Absorbsi 


\section{PENDAHULUAN}

Beton merupakan struktur yang cukup vital dalam sebuah konstruksi. Beton terdiri dari air semen agregat halus dan agregat kasar. Umumnya beton yang memiliki mutu tinggi juga memerlukan bahan dengan mutu yang tinggi,baik dari segi agregat kasar,agregat halus,semen maupun air akan menentukan kualitas dan kekuatan dari beton tersebut. Hal tersebut berbanding lurus dengan nilai kebutuhan semen, dimana kebutuhan semen di indonesia terus meningkat.

Selain itu, tercatat data angka kebutuhan semen mencapai 20 juta ton dalam kurun waktu 2012-2016 (Asosiasi Semen Indonesia, 2016).Menurut Djwantoro Hardjito (2007), teknologi produksi semen diIndonesia cenderung boros energy dan menimbulkan emisi $\mathrm{CO}_{2}$ yang menyumbang pada kenaikan suhu global. Sehubungan dengan hal itu, maka dilakukan penelitian sebagai upaya untuk menemukan sumber lain sebagai bahan alternative pengganti sebagian semen. Bahan alternative tersebut didapat dengan cara memanfaatkan limbah-limbah industry dan konstruksi yang selama ini dibiarkan dan dibuang begitu saja. Salah satu limbah industry konstruksi yang dapat dimanfaatkan adalah limbah produksi genteng dan sebagian campuran semen, [1][2][3].

Limbah Genteng memiliki keunggulan yaitu bahan baku untuk pembuatannya yang merupakan tanah liat mudah didapat dengan persediaan yang cukup. Dengan penelitian ini di harapkan limbah dari genteng dapat menjadi pengganti sebagian dari semen yang selama ini menjadi bahan pokok beton,sehingga akan mengurangi jumlah penggunaa semen untuk konstruksi. dengan dilakukan penambahan zat additive berjenis MASTER EASEsebagai zat atau cairan untuk meningkatkan mutu beton [4][5][6]. Bahan lain seperti batu koral dan pasir yang digunakan adalah pasir dari daerah kediri, tepatnya dari kecamatan plosoklatem kabupaten kediri, untuk batu koral menggunakan batu pecah manual yang di beli dari kecamatan Semen Kota Kediri.

\section{METODE PENELITIAN}

\subsection{Lokasi Penelitian.}

Penelitian ini dilakukan di Laboratorium Teknik Sipil Universitas Kadiri, pada awal bulan maret dan selesai pada bulan juni dengan menggunakan metode Eksperimen.

\subsection{Beton}

Beton merupakan komponen yang cukup vital dalam sebuah konstruksi. Beton terdiri dari air semen agregat halus dan agregat kasar [7][8][9]. Umumnya beton yang memiliki mutu tinggi juga memerlukan bahan dengan mutu yang tinggi,baik dari segi agregat kasar,agregat 
halus,semen maupun air akan menentukan kualitas dan kekuatan dari beton tersebut[10]. Hal tersebut berbanding lurus dengan nilai kebutuhan semen, dimana kebutuhan semen di indonesia terus meningkat, [11][12].

\subsection{Jenis-jenis Beton}

Dalam pengaplikasiannya dalam dunia konstruksi, Beton dibagi menjadi beberapa jenis, antara lain adalah sebagai berikut :

\subsubsection{Beton Mutu Tinggi}

Beton mutu tinggi adalah beton dengan nilai kuat tekan di atas K-350. Yangumumnya beton tersebut memiliki kuat tekan tinggi sehingga diperuntuk bangunan struktur.[13].

\subsubsection{Beton Mutu Sedang}

Beton mutu sedang umumnya memiliki nilai K-300 hingga K-150 yang berarti memiliki kuat tekan sedang biasanya untuk penggunaan pada rumah tinggal maupun gedung yang memiliki beban tidak teralu tinggi.[11][14]

\subsubsection{Beton Mutu Rendah}

Beton mutu tendah umumnya memiliki nilai dibawah K-150. Biasanya di gunakan untuk paving taman maupun bangunan ringan[15]

\subsection{Bahan Penyusu Beton}

Bahan yang digunakan untuk pembuatan beton secara umumnya berupa pasir, air, semen dan koral, [16].

\subsubsection{Semen}

Semen merupakan zat perekat pada beton yang bersifat hidrolis dengan cara menghaluskan batuan batuan silikat kalsium dan batuan gypsum yang dapat bereaksi dengan air untuk membentuk zat padat baru [10][17].

\subsubsection{Pasir}

Pasir umumnya digunakan sebagai agregat halus untuk pembuatan beton, fungsi pasir sebagai campuran atau pengisi rongga beton, Pasir yang berasal dari lereng gunung kelud dan di beli dari tambang pasir di wilayah kecamatan plosoklaten [18].

\subsubsection{Batu Belah (Koral)}

Batu yang biasanya digunakan untuk bahan pembuatan beton umumnya menggunakan batu yang keras yaitu batu yang lolos proses abrasi, biasanya batu keras adalah batu dari erupsi gunung [19][20]. 


\subsubsection{Limbah Genteng}

Limbah genteng tersebut diperoleh dari pabrik genteng di wilayah desa Gandusari Kabupaten Trenggalek.

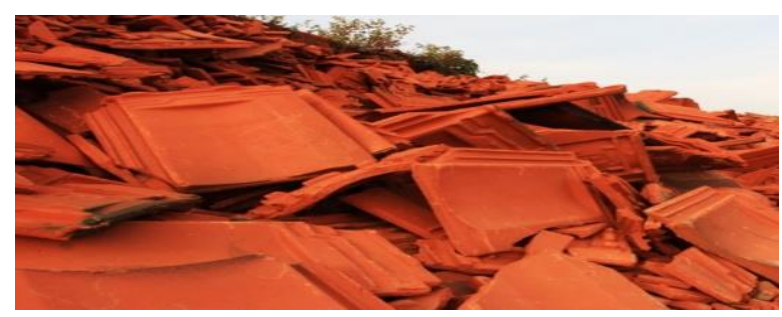

Sumber : Pabrik Genteng Mantili

Gambar2.1 Limbah Genteng Yang Tidak Terpakai

\subsubsection{Air}

Air pada pembuatan beton digunakan sebagai bahan pereaksi untuk semen yang menjadiakan semen agregat halus dan agregat kasar menyatu enjadi sebuah beton.

\subsection{Perencanaan Penelitian}

Proses pembuatan beton hingga pengetesan beton

Proses pertama yaitu pengambilan pasir (agregat halus) menggunakan ayakan lolos berdiameter 0,40 $\mathrm{mm}$ dan tertahan pada ayakan berdiameter $0,39,2) P a s i r$ di oven 3) Menyediakan batu belah atau koral, semen type 1, air, limbah genteng bubuk, zat aditif master ease yang telah di siapkan. 4) Proses mixing menggunakan media mesin pengaduk elektrik. 5) Masukan air, Zat Additive Master Ease, limbah genteng yang telah dihaluskan dan semen kedalam mesin pengaduk. 6) Putar mesin pengaduk selama 10 menit. 7) Masukan Batu belah atau koral pada mesin pengaduk sedikit demi sedikit secara bertahap. 8) Setelah seluruh bahan telah tercampur dengan campuran Air, pada 15 menit putaran Mixer dan masukkan pasir secara bertahap. 9) di uji test slump. 10)padatkan menggunakan alat penusuk baja dan getarkan dicetakanBiarkan Beton mengering hingga sempurna, antara 5-7 Hari. 11) Setelah beton kering, bongkar cetakan beton dan lakuan proses selanjutnya yaitu proses curing beton atau merendam beton kedalam kolam selama waktu analisa 28 hari. 12)Angkat Beton dari kolam curing dan angin-anginkan Beton selama 1 hari untuk proses pengeringan. kemudian uji tekan beton

\section{HASIL DAN PEMBAHASAN}

\subsection{Hasil Pengujian Kuat Tekan Benda Uji}

Tabel 1. Tabel Test Kuat Tekan Beton dengan penambahan Limbah Genteng 5\% dari semen dan zat additive $5 \%$ dari air 


\begin{tabular}{|c|c|c|c|c|c|c|}
\hline NO & Benda Uji & $\begin{array}{c}\text { Angka Dial } \\
\text { Ton }\end{array}$ & $\begin{array}{c}\text { Angka Dial } \\
\text { di Jadikan Kg }\end{array}$ & Luaspenampang & Hasil test ( K ) KuatTekan (Kg/cm²) \\
\hline 1 & Sampel 1 & 50 & 50000 & 225 & 222,22 \\
\hline 2 & Sampel 2 & 46 & 46000 & 225 & 204,44 \\
\hline 3 & Sampel 3 & 46 & 46000 & 225 & 225 & 213,33 \\
\hline 4 & \multicolumn{7}{|c|}{ Sampel 4 } & 48 & 48000 & 225 & 217,78 \\
\hline 5 & \multicolumn{7}{|c|}{ Sampel 5 } & 49 & 49000 & & 212,44 \\
\hline
\end{tabular}

Sumber : Data Diolah

Tabel 2. Tabel Test Kuat Tekan Beton dengan penambahan Limbah Genteng 10\% dari semen dan zat additive $5 \%$ dari air

\begin{tabular}{|c|c|c|c|c|c|}
\hline NO & Benda Uji & $\begin{array}{c}\text { Angka } \\
\text { Dial Ton }\end{array}$ & $\begin{array}{c}\text { Angka Dial } \\
\text { di Jadikan } \\
\text { Kg }\end{array}$ & $\begin{array}{c}\text { Luas } \\
\text { penampang }\end{array}$ & $\begin{array}{c}\text { Hasil test ( K ) Kuat Tekan } \\
\left(\mathrm{Kg} / \mathrm{cm}^{2}\right)\end{array}$ \\
\hline 1 & Sampel 1 & 44 & 44000 & 225 & 195,56 \\
\hline 2 & Sampel 2 & 46 & 46000 & 225 & 204,44 \\
\hline 3 & Sampel 3 & 46 & 46000 & 225 & 204,44 \\
\hline 4 & Sampel 4 & 45 & 45000 & 225 & 204,44 \\
\hline 5 & Sampel 5 & 46 & 46000 & 225 & 201,78 \\
\hline
\end{tabular}

\section{Sumber : Data Diolah}

Tabel3. Tabel Test Kuat Tekan Beton dengan penambahan Limbah Genteng 15\% dari semen dan zat additive $5 \%$ dari air

\begin{tabular}{|c|c|c|l|c|c|}
\hline NO & Benda Uji & $\begin{array}{c}\text { Angka Dial } \\
\text { Ton }\end{array}$ & $\begin{array}{c}\text { Angka Dial di } \\
\text { Jadikan Kg }\end{array}$ & $\begin{array}{c}\text { Luas penampang } \\
15 \times 15 \mathrm{~cm}(\mathrm{~A})\end{array}$ & Hasil test ( K ) KuatTekan $\left(\mathrm{Kg} / \mathrm{cm}^{2}\right)$ \\
\hline 1 & Sampel 1 & 42 & 42000 & 225 & 186,67 \\
\hline 2 & Sampel 2 & 43 & 43000 & 225 & 191,11 \\
\hline 3 & Sampl 3 & 45 & 45000 & 225 & 200,00 \\
\hline 4 & Sampel 4 & 43 & 43000 & 225 & 191,11 \\
\hline 5 & Sampel 5 & 42 & 42000 & 225 & 186,67 \\
\hline \multicolumn{5}{|c|}{ rata-rata } \\
\hline
\end{tabular}


Sumber : Data Diolah

Tabel 4. Test Kuat Tekan Beton Normal

\begin{tabular}{|c|c|c|c|c|c|}
\hline NO & Benda Uji & $\begin{array}{c}\text { Angka Dial } \\
\text { Ton }\end{array}$ & $\begin{array}{c}\text { Angka Dial di } \\
\text { Jadikan Kg }\end{array}$ & $\begin{array}{c}\text { Luaspenampang } \\
15 \times 15 \mathrm{~cm}(\mathrm{~A})\end{array}$ & Hasil test ( K ) KuatTekan $\left(\mathrm{Kg} / \mathrm{cm}^{2}\right)$ \\
\hline 1 & Sampel 1 & 45 & 45000 & 225 & 200,00 \\
\hline 2 & Sampel 2 & 47 & 47000 & 225 & 208,89 \\
\hline 3 & Sampel 3 & 45 & 45000 & 225 & 186,67 \\
\hline 4 & Sampel 4 & 42 & 42000 & 225 & 208,89 \\
\hline 5 & Sampel 5 & 47 & 47000 & 225 & 200,89 \\
\hline \multicolumn{5}{|c|}{ rata-rata } \\
\hline
\end{tabular}

Sumber : Data Diolah variabel.

Di bawah ini adalah diagram dari kuat tekan dari keseluruhan sampel dari masing masing

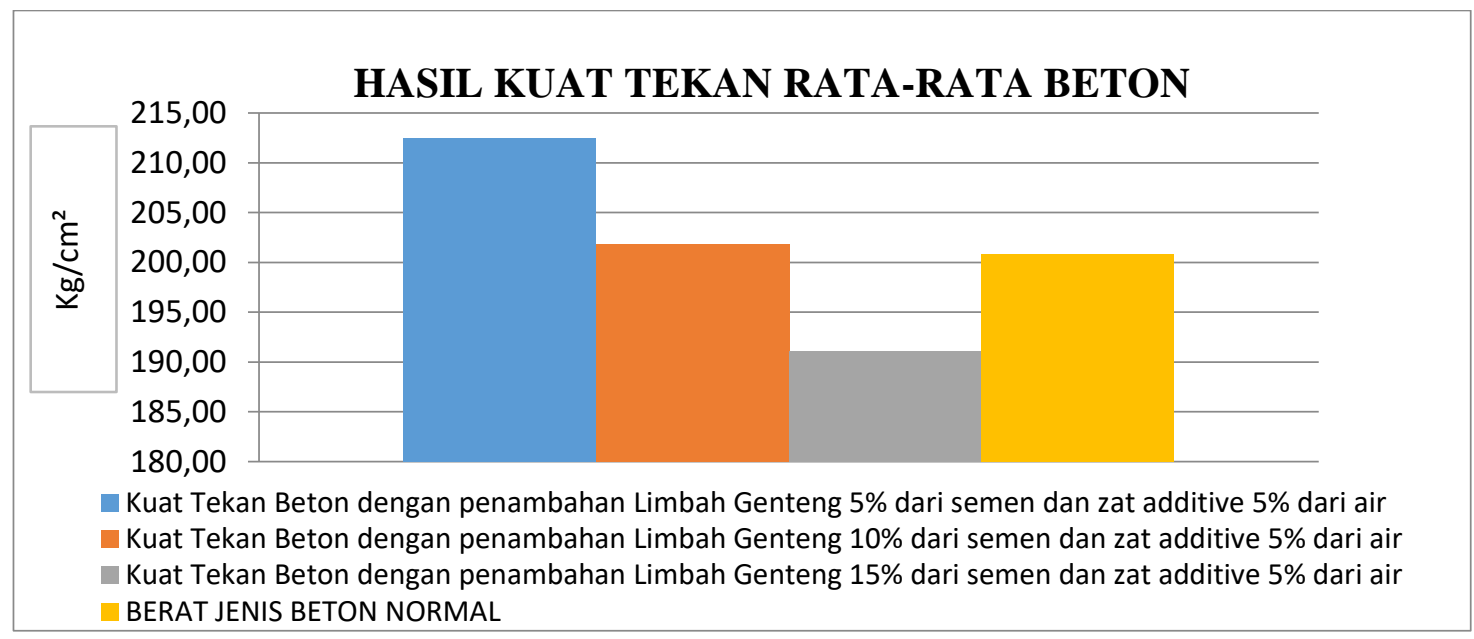

Sumber : Data Diolah

Grafik 1. Diagram Kuat Tekan Masing-Masing Sampel

Dari hasil percobaan di atas dapat di ambil kesimpulan bahwa beton yang memiliki nilai kuat tekan rata-rata paling tinggi di miliki beton dengan penambahan Limbah Genteng 5\% dari semen dan zat additive $5 \%$ dari air dengan nilai kuat tekan sebesar $212,44 \mathrm{Kg} / \mathrm{cm}^{2}$, dan yang memiliki nilai kuat tekan paling rendah di miliki beton dengan penambahan Limbah Genteng $15 \%$ dari semen dan zat additive $5 \%$ dari air dengan nilai kuat tekan $191,11 \mathrm{Kg} / \mathrm{cm}^{2}$.

\subsection{Hasil Pengujian Absorsi}

Tabel 5. Tabel Data Absorsi Beton dengan penambahan Limbah Genteng 5\% dari semen dan zat additive $5 \%$ dari air 


\begin{tabular}{|l|c|c|c|}
\hline \multirow{2}{*}{ Benda uji } & \multicolumn{2}{|c|}{ Waktu Perendaman } & Hasil Absorsi (L) \\
\cline { 2 - 4 } & Berat Kering (Ws) & 24 Jam & 24 jam \\
\hline Sampel 1 & 8,144 & 8,289 & 0,1450 \\
\hline Sampel 2 & 8,185 & 8,360 & 0,1749 \\
\hline Sampel 3 & 7,997 & 8,141 & 0,1440 \\
\hline Sampel 4 & 7,980 & 8,174 & 0,1937 \\
\hline Sampel 5 & 8,210 & 8,403 & 0,1933 \\
\hline & & Rata-Rata & 0,1702 \\
\hline
\end{tabular}

Sumber : Data Diolah

Tabel 6. Tabel Data Absorsi Beton dengan penambahan Limbah Genteng 10\% dari semen dan zat additive $5 \%$ dari air

\begin{tabular}{|l|c|c|c|}
\hline \multirow{2}{*}{ Benda uji } & \multicolumn{2}{|c|}{ Waktu Perendaman } & Hasil Absorsi (L) \\
\cline { 2 - 4 } & Berat Kering (Ws) & 24 Jam & 24 jam \\
\hline Sampel 1 & 8,211 & 8,3233 & 0,1123 \\
\hline Sampel 2 & 8,120 & 8,2722 & 0,1522 \\
\hline Sampel 3 & 8,010 & 8,2223 & 0,2123 \\
\hline Sampel 4 & 8,210 & 8,4032 & 0,1932 \\
\hline Sampel 5 & 7,960 & 8,0842 & 0,1242 \\
\hline & & Rata-Rata & 0,1589 \\
\hline
\end{tabular}

\section{Sumber : Data Diolah}

Tabel 7. Tabel Data Absorsi Beton dengan penambahan Limbah Genteng 15\% dari semen dan zat additive $5 \%$ dari air

\begin{tabular}{|l|c|c|c|}
\hline \multirow{2}{*}{ Benda uji } & \multicolumn{2}{|c|}{ Waktu Perendaman } & \multicolumn{1}{l|}{ Hasil Absorsi (L) } \\
\cline { 2 - 4 } & Berat Kering (Ws) & 24 Jam & 24 jam \\
\hline Sampel 1 & 8,160 & 8,3744 & 0,2144 \\
\hline Sampel 2 & 8,155 & 8,3214 & 0,1664 \\
\hline Sampel 3 & 8,211 & 8,4434 & 0,2324 \\
\hline Sampel 4 & 8,050 & 8,2063 & 0,1563 \\
\hline Sampel 5 & 7,960 & 8,1444 & 0,1844 \\
\hline & & Rata-Rata & 0,1908 \\
\hline
\end{tabular}

Sumber : Data Diolah 
Tabel 8. Tabel Data Absorsi Beton Normal

\begin{tabular}{|l|c|c|c|}
\hline \multirow{2}{*}{ Benda uji } & \multicolumn{2}{|c|}{ Waktu Perendaman } & Hasil Absorsi (L) \\
\cline { 2 - 4 } & Berat Kering (Ws) & 24 Jam & 24 jam \\
\hline Sampel 1 & 8,150 & 8,2899 & 0,1399 \\
\hline Sampel 2 & 8,110 & 8,3080 & 0,1980 \\
\hline Sampel 3 & 8,010 & 8,1730 & 0,1630 \\
\hline Sampel 4 & 8,210 & 8,4030 & 0,1930 \\
\hline Sampel 5 & 8,130 & 8,2863 & 0,1563 \\
\hline & & Rata-Rata & 0,1700 \\
\hline
\end{tabular}

Sumber : Data Diolah

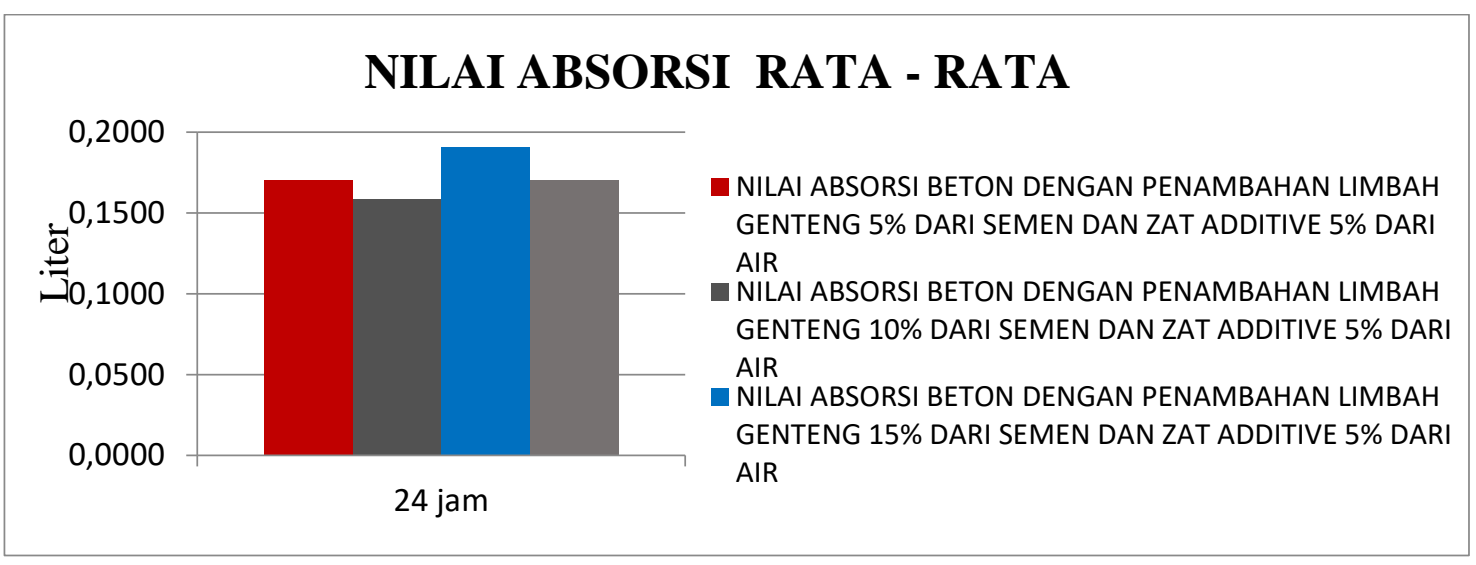

Sumber : Data Diolah

Grafik 2. Diagram Dari Rata-Rata Sampel

Dari grafik di atas dapat di simpulkan bahwa nilai serap terhadap air setelah beton di rendam selama 24 jam paling tinggi dimiliki oleh beton menggunakan Beton dengan penambahan Limbah Genteng 15\% dari semen dan zat additive 5\% dari air di dapat nilai penyerapan air setelah proses perendaman selama 24 jam yaitu senilai 0,1908 liter, sedangkan untuk nilai paling rendah daya serap beton terhadap air yang di rendam selama 24 jam dimiliki oleh beton dengan campuran penambahan Limbah Genteng 10\% dari semen dan zat additive 5\% dari air dapat di ambil nilai rata-rata penyerapan beton terhadap air selama 24 jam perendaman mencapai nilia 0,1589 liter

\subsection{Hasil Pengujian Berat Jenis Benda Uji}

Tabel 8. Hasil Perhitungan Berat Jenis Beton dengan campuran penambahan Limbah Genteng 5\% dari semen dan zat additive 5\% dari air 


\begin{tabular}{|c|c|c|c|c|}
\hline NO & Sampel & Berat Total (W) Kg & Volume Total $(\mathrm{V}) \mathrm{m}^{3}$ & BeratjenisBeton $\left(\mathrm{kg} / \mathrm{m}^{3}\right)$ \\
\hline 1 & Sampel 1 & 8,14 & 0,003375 & 2413,04 \\
\hline 2 & Sampel 2 & 8,19 & 0,003375 & 2425,19 \\
\hline 3 & Sampel 3 & 8,00 & 0,003375 & 2369,48 \\
\hline 4 & Sampel 4 & 7,98 & 0,003375 & 2364,44 \\
\hline 5 & Sampel 5 & 8,21 & 0,003375 & 2432,59 \\
\hline \multicolumn{3}{|c|}{ Beratjenis rata-rata } & 2400,95 \\
\hline
\end{tabular}

Sumber : Data Diolah

Tabel 9. Hasil Perhitungan Berat Jenis Beton dengan campuran penambahan Limbah Genteng $10 \%$ dari semen dan zat additive $5 \%$ dari air

\begin{tabular}{|c|c|c|c|c|}
\hline NO & Sampel & Berat Total $(\mathrm{W}) \mathrm{Kg}$ & Volume Total $(\mathrm{V}) \mathrm{m}^{3}$ & BeratjenisBeton $\left(\mathrm{kg} / \mathrm{m}^{3}\right)$ \\
\hline 1 & Sampel 1 & 8,21 & 0,003375 & 2432,89 \\
\hline 2 & Sampel 2 & 8,12 & 0,003375 & 2405,93 \\
\hline 3 & Sampel 3 & 8,01 & 0,003375 & 2373,33 \\
\hline 4 & Sampel 4 & 8,21 & 0,003375 & 2432,59 \\
\hline 5 & Sampel 5 & 7,96 & 0,003375 & 2358,52 \\
\hline \multicolumn{3}{|c|}{ Beratjenis rata-rata } & 2400,65 \\
\hline
\end{tabular}

Sumber : Data Diolah

Tabel 10. Hasil Perhitungan Berat Jenis Beton dengan campuran penambahan Limbah Genteng $15 \%$ dari semen danzat additive $5 \%$ dari air

\begin{tabular}{|c|c|c|c|c|}
\hline NO & Sampel & Berat Total $(\mathrm{W}) \mathrm{Kg}$ & Volume Total $(\mathrm{V}) \mathrm{m}^{3}$ & BeratjenisBeton $\left(\mathrm{kg} / \mathrm{m}^{3}\right)$ \\
\hline 1 & Sampel 1 & 8,16 & 0,003375 & 2417,78 \\
\hline 2 & Sampel 2 & 8,16 & 0,003375 & 2416,30 \\
\hline 3 & Sampel 3 & 8,21 & 0,003375 & 2432,89 \\
\hline 4 & Sampel 4 & 8,05 & 0,003375 & 2385,19 \\
\hline 5 & Sampel 5 & 7,96 & 0,003375 & 2358,52 \\
\hline \multicolumn{3}{|c|}{ Beratjenis rata-rata } & 2402,13 \\
\hline
\end{tabular}

Sumber : Data Diolah

Tabel 11. Hasil Perhitungan Berat Jenis Beton Normal 


\begin{tabular}{|c|c|c|c|c|}
\hline NO & Sampel & Berat Total $(\mathrm{W}) \mathrm{Kg}$ & Volume Total $(\mathrm{V}) \mathrm{m}^{3}$ & BeratjenisBeton $\left(\mathrm{kg} / \mathrm{m}^{3}\right)$ \\
\hline 1 & Sampel 1 & 8,15 & 0,003375 & 2414,81 \\
\hline 2 & Sampel 2 & 8,11 & 0,003375 & 2402,96 \\
\hline 3 & Sampel 3 & 8,01 & 0,003375 & 2373,33 \\
\hline 4 & Sampel 4 & 8,21 & 0,003375 & 2432,59 \\
\hline 5 & Sampel 5 & 8,13 & 0,003375 & 2408,89 \\
\hline \multicolumn{3}{|c|}{ Beratjenis rata-rata } & 2406,52 \\
\hline
\end{tabular}

Sumber : Data Diolah

Untuk nilai berat jenis beton dengan campuran penambahan Limbah Genteng 5\% dari semen dan zat additive $5 \%$ dari air mencapai nilai $2400,95 \mathrm{~kg} / \mathrm{m}^{3}$, Pada penambahan Limbah Genteng $10 \%$ dari semen dan zat additive $5 \%$ dari air mencapai nilai $2400,65 \mathrm{~kg} / \mathrm{m}^{3} \mathrm{Dan}$ pada penambahan Limbah Genteng 15\% dari semen dan zat additive 5\% dari air mencapai nilai $2402,13 \mathrm{~kg} / \mathrm{m}^{3}$, Sedangkan berat jenis beton normal memiliki nilai berat jenis $2406,52 \mathrm{~kg} / \mathrm{m}^{3}$.

\section{KESIMPULAN}

Berdasarkan penelitian yang telah dilakukan di laboraturium Universitas Kadiri di dapatkan hasil sebagai berikut :

1. Dari penelitian kuat tekan ini dapat kita kesimpulan bahwa beton yang memiliki nilai kuat tekan rata-rata paling tinggi di miliki beton dengan penambahan Limbah Genteng 5\% dari semen dan zat additive $5 \%$ dari air dengan nilai kuat tekan sebesar $212,44 \mathrm{Kg} / \mathrm{cm}^{2}$, dan yang memiliki nilai kuat tekan paling rendah di miliki beton dengan penambahan Limbah Genteng $15 \%$ dari semen dan zat additive $5 \%$ dari air dengan nilai kuat tekan $191,11 \mathrm{Kg} / \mathrm{cm}^{2}$

2. Untuk penelitian dari daya serap beton terhadap air dapat di simpulkan bahwa nilai serap terhadap air setelah beton di rendam selama 24 jam paling tinggi dimiliki oleh beton menggunakan Beton dengan penambahan Limbah Genteng 15\% dari semen dan zat additive $5 \%$ dari air di dapat nilai penyerapan air setelah proses perendaman selama 24 jam yaitu senilai 0,1908 liter, sedangkan untuk nilai paling rendah daya serap beton terhadap air yang di rendam selama 24 jam dimiliki oleh beton dengan campuran penambahan Limbah Genteng 10\% dari semen dan zat additive 5\% dari air dapat di ambil nilai rata-rata penyerapan beton terhadap air selama 24 jam perendaman mencapai nilia 0,1589 liter

3. Untuk nilai berat jenis beton dari ke empat variabel tersebut dapat di ambil kesimpulan untuk beton yang memiliki rata-rata berat jenis paling rendah adalah variabel campuran penambahan Limbah Genteng 10\% dari semen dan zat additive 5\% dari air, dan yang memiliki berat jenis 
paling tinggi adalah beton normal.

\section{SARAN}

Dari penelitian di atas seharusnya dilakukan penelitian lebih lanjut sehingga penggantian agregat tersebut dapat dilaksanakan secara efektif dan efisien, selain itu juga perlu di adakan pengetesetan pada jangka panjang.

\section{UCAPAN TERIMAKASIH}

Dalam penyusunan artikel ini, penulis ucapkan terimakasih kepada dosen pembimbing dan Universitas Kadiri. Penulis berharap agar artikel ini dapat bermanfaat bagi pembaca.

\section{DAFTAR PUSTAKA}

[1] M. S. Wiwoho, M. Machicky, and R. Nawir, "Bamboo Waste as Part of The Aggregate Pavement The Way Green Infrastructure in The Future," in MATEC Web of Conferences, 2017, vol. 138, p. 3013.

[2] A. I. Candra, A. Yusuf, and A. R. F, "Studi Analisis Daya Dukung Pondasi Tiang Pada Pembangunan Gedung Lp3M Universitas Kadiri,” J. CIVILA, vol. 3, no. 2, p. 166, 2018, doi: 10.30736/cvl.v3i2.259.

[3] et al Rompas, "Pengaruh Pemanfaatan Abu Ampas Tebu Sebagai Substitusi Parsial Semen Dalam Campuran Beton Ditinjau Terhadap Kuat Tarik Lentur Dan Modulus Elastisitas,” J. Sipil Statik, vol. 1, no. 2, pp. 82-89, 2013.

[4] M. A. Anshori, "PENELITIAN UJI KUAT TEKAN BETON DENGAN MEMANFAATKAN AIR LIMBAH TETES TEBU DAN ZAT ADDITIVE CONCRETE," jurmateks, vol. 2, no. 1, pp. 11-22, 2019, doi: http://dx.doi.org/10.30737/jurmateks.v2i1.388.

[5] Gemelly Katrina, "Pemanfaatan Limbah Kulit Kerang sebagai Subsitusi dan Abu Ampas Tebu Sebagai Subsitusi Semen pada Campuran Beton Mutu K-225,” J. Tek. Sipil dan Lingkung., vol. 2, no. 3, pp. 308-313, 2014.

[6] D. Setyawan, F. Saleh, and H. Payuda, "Pengaruh Variasi Penambahan Abu Ampas Tebu Terhadap Flowability Dan Kuat Tekan Self Compacting Concrete," J. Rekayasa Sipil, vol. 12, no. 2, p. 111, 2016, doi: 10.25077/jrs.12.2.111-120.2016.

[7] T. P. G. A, Y. C. S. P, S. Winarto, and A. I. Candra, "PERBANDINGAN KEKUATAN BETON DENGAN CAMPURAN DRAMIX STEEL FIBER DAN TULANGAN WIREMESH PADA RIGID PAVEMENT,” Jurmateks, vol. 1, no. 2, pp. 313-324, 2018. 
[8] A. Ridwan and A. Chandra, "Jobmix beton mengunakan pasir lumajang dan penambahan additive masterpozzolith ® 402r," J. CIVILA, vol. 3, no. 2, pp. 192-197, 2018.

[9] F. P. Pane, H. Tanudjaja, and R. S. Windah, "Pengujian Kuat Tarik Lentur Beton Dengan Variasi Kuat Tekan Beton," J. Sipil Statik, vol. 3, no. 5, pp. 313-321, 2015.

[10] A. I. Candra, E. Gardjito, Y. Cahyo, and G. A. Prasetyo, "Pemanfaatan Limbah Puntung Rokok Filter Sebagai Bahan Campuran Beton Ringan Berpori,” UKaRsT, vol. 3, no. 1, p. 82, 2019, doi: 10.30737/ukarst.v3i1.365.

[11] E. Gardjito, A. I. Candra, and Y. Cahyo, "PENGARUH PENAMBAHAN BATU KARANG SEBAGAI,” pp. 36-42.

[12] M. E. Zakariya, "Pengaruh Penambahan Serat Sabut Kelapa Dengan Penggunaan Catalyst, Monomer, Dan Fly Ash Sebagai Material Penyusun Beton Ringan Seluler,” J. Rekayasa Tek. Sipil, vol. 1, no. 1, pp. 186-194, 2018.

[13] A. Iwan and E. Siswanto, "MENGGUNAKAN HYDROTON DAN MASTER EASE 5010,” J. CIVILLa, vol. 3, no. 2, pp. 162-165, 2018.

[14] H. Prayuda and A. Pujianto, "Analisis Kuat Tekan Beton Mutu Tinggi Dengan Bahan Tambah Superplastisizer dan Limbah Las Karbit,” Rekayasa Sipil, vol. 12, no. 1, pp. 32 38, 2018, doi: 10.21776/ub.rekayasasipi1/2018.012.01.5.

[15] E. Siswanto, "Penambahan Fly Ash Dan Serat Serabut Kelapa Sebagai Bahan Pembuatan Beton," UKaRsT, vol. 3, no. 1, p. 48, 2019, doi: 10.30737/ukarst.v3i1.352.

[16] Badan Standarisasi Nasional, "SNI 7656-2012 Tata Cara Pemilihan Campuran Beton Normal, Beton Berat, dan beton Massa," 2012.

[17] N. Usrina, T. B. Aulia, and M. Muttaqin, "Kuat Tekan Beton Mutu Tinggi Hybrid Dengan Substitusi Semen Dan Agregat Halus Serta Penambahan Nano Material Bijih Besi,” J. Arsip Rekayasa Sipil dan Perenc., vol. 1, no. 1, pp. 179-188, 2018, doi: 10.24815/jarsp.v1i1.10368.

[18] S. F. Romadhoni, A. Ridwan, S. Winarto, and A. I. Candra, "STUDI EXPERIMEN KUAT TEKAN BETON DENGAN MEMANFAATKAN LIMBAH KERAMIK DAN BATA MERAH,”Jurmateks, vol. 2, no. 1, pp. 86-95, 2019.

[19] M. A. Anshori, A. Ridwan, and Y. C. S. P, "PENELITIAN UJI KUAT TEKAN BETON DENGAN MEMANFAATKAN AIR LIMBAH TETES TEBU DAN ZAT ADDITIVE CONCRETE," Jurmateks, vol. 2, no. 1, pp. 16-27, 2019.

[20] A. D. Krisna, S. Winarto, and A. Ridwan, "PENELITIAN UJI KUAT TEKAN BETON DENGAN MEMANFAATKAN LIMBAH AMPAS TEBU DAN ZAT ADDITIF SIKACIM BONDING ADHESIVE,” Jurmateks, vol. 2, no. 1, pp. 1-15, 2019. 